\title{
TWO NEW SPECIES OF SCARIS LE PELETIER \& SERVILLE (HOMOPTERA, CICADELLIDAE, GYPONINAE) FROM BRAZIL
}

\author{
Luci Boa Nova Coelho ${ }^{1}$
}

\begin{abstract}
Scaris bahiensis, sp.n. is described based on an adult male from Bahia. It is not closely related to any species of its genus. Scaris nessimiani, sp.n., related to S. defecta DeLong \& Freytag, 1969, is described based on an adult male from Mato Grosso.

KEY WORDS. Homoptera, Cicadellidae, Gyponinae, new species
\end{abstract}

\section{Scaris bahiensis, sp.n.}

Figs 1-7

Length of male $12 \mathrm{~mm}$, female unknown. Crown pale brown, nearly three times as wide between eyes at base as the median length; transverse striae changing in oblique ones between ocelli. Ocelli red, 1.5 time closer to proximal eyes than to median line. Face pale brown, post-clypeus with numerous dark lateral arcs; anteclipeus with two small spots laterally to the median line; genae with a dark elongated spot. Pronotum pale brown, striated transversally, with small brown spots on the central area and a narrow transverse dark brown band wavyly outlined on the posterior margin, nearly two times as wide as median length. Forewing pale brown with a brown spot on its base; claval veins with a reddish brown spot on the apex; venation reddish brown; appendix developed, with two dark spots.

Male genitalia. Subgenital plate three times as long as broad, narrowed and rounded at the apex. Style stout, sharp-pointed apically, curved outside; a leaf-like projection on its subapical region, thinly toothed on the outer margin. Aedeagus short, curving upward, with longitudinal latero-ventral folds all along the shaft, in ventral view; a single short ventro-basal process at the middle, with the truncate apex pointing downward; apex of shaft with a pair of short and delicate dorsal processes and a latero-dorsal keel-shaped expansion; terminal gonopore covered by an apical membrane. Pygofer truncate at apex, with a slender dorsal anterior process on each side, extending into capsule and a hemispherical latero-ventral fold, in the median third.

Holotype male. BRAZIL, Bahia, Encruzilhada, XI-1972, M. Alvarenga leg., Entomological Collection of the Department Zoologia, Institute Biologia, Universidade Federal do Rio de Janeiro.

1) Departamento de Zoologia, Universidade Federal do Rio de Janeiro, Caixa Postal 68044, 21949-900 Rio de Janeiro, Rio de Janeiro, Brasil. 

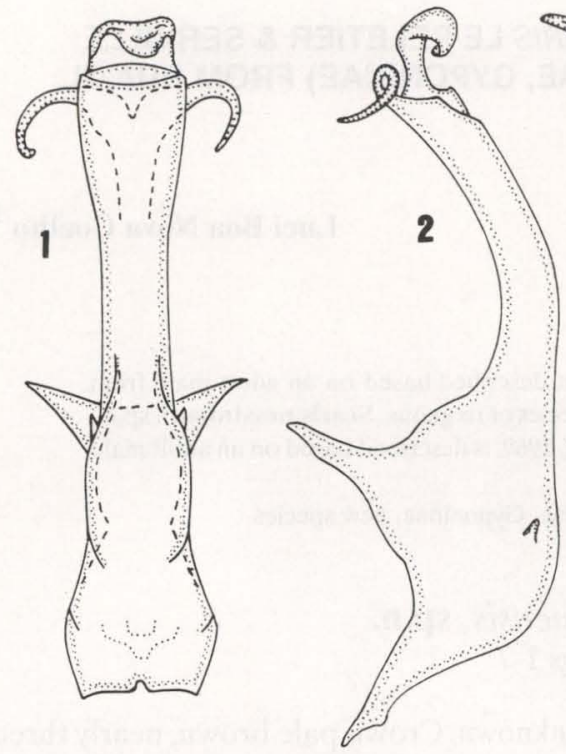

0.5
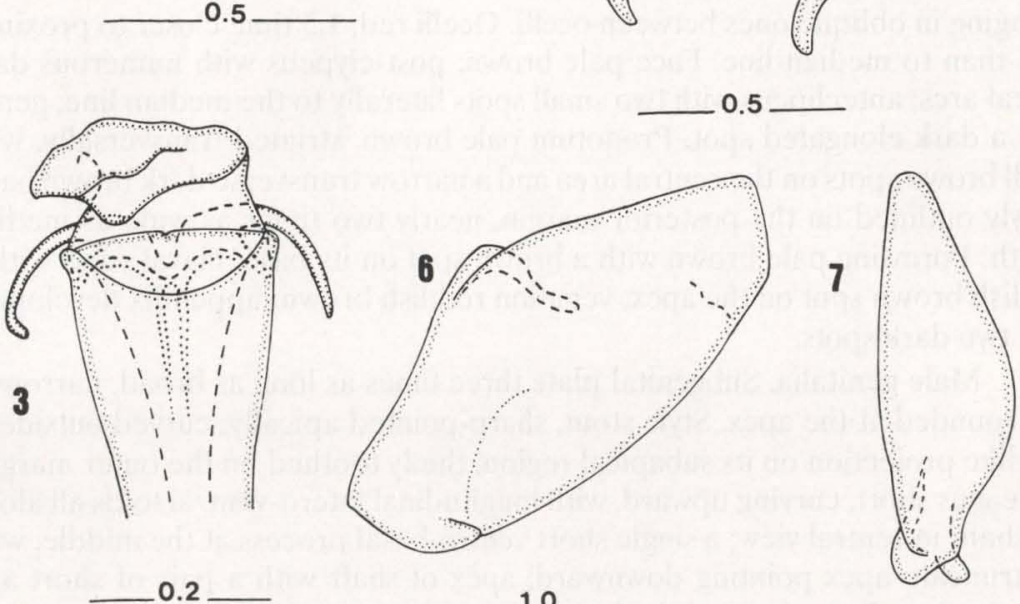

1.0

Figs 1-7. Scaris bahiensis, sp.n. (1) Aedeagus, ventrally; (2) aedeagus, laterally; (3) apical region of the aedeagus, ventrally; (4) style, ventrally; (5) style, laterally; (6) pygofer, laterally; (7) subgenital plate, ventrally. Scale in milimeters.

Discussion. Scaris bahiensis, sp.n. is similar to several species of its genus in colour pattern and shape of the subgenital plates. Nevertheless, the new species is not closely related to any other species, because of its singular ventral process on the aedeagus base.

Etymology. The name of this species is relative to its type locality, Bahia, Brazil. 


\section{Scaris nessimiani, sp.n.}

\section{Figs 8-14}

Length of male $11 \mathrm{~mm}$, female unknown. Crown orange-yellow, five times as wide between eyes at base as median length, striated transversally. Ocelli red, 1.5 time closer to proximal eyes than to median line. Face pale-yellow. Pronotum of the same colour pattern as the crown, with a narrow transverse brown band wavyly outlined; striated transversally; nearly 1.5 time as wide as median length. Scutellum pale brown with brown spots, basal half smooth with latero-basal spots; a pair of sickle-like spots in each side, close the proximal median line; scutellar suture strongly marked and with a median small spot; apical half striated transversally, with a spot in each side of the median line, lateral borders brown from lateral angles to apex. Forewing pale brown, translucent, venation pale-yellow, thinly outlined by reddish brown, with small dark brown and reddish brown spots; appendix developed with two dark brown spots.

Male genitalia. Subgenital plate nearly five times as long as broad, narrowed and rounded at the apex. Style stout, irregularly toothed on the inner margin of the subapical region; apex of the style narrowed, bent outwardly. Aedeagus stout in ventral view, enlarged at base with latero-ventral longitudinal folds reaching approximately one-half of the length of the shaft, that presents a pair of short lateral spines; apical region enlarged, curving upward with a pair of dorso-lateral processes; apical gonopore covered by a delicate membrane, elongated dorsally, anterior to the pair of processes, curved toward ventral region. Pygofer obtuse at apex and with a dorsal anterior process on each side in lateral view, extending into the capsule and a weak latero-ventral external fold in the anterior region.

Holotype male. BrazIL, Mato Grosso, Manso (Usina Hidrelétrica de Manso), VI-1988, leg. J.L. Nessimian, Entomological Collection of the Departamento de Zoologia, Instituto de Biologia, Universidade Federal do Rio de Janeiro.

Discussion. S. nessimiani, sp.n. is more closely related to $S$. defecta (DeLong \& Freytag, 1969), because of the general shape of their genital structures.

Etymology. The name of this species is dedicated to the Professor Jorge Luiz Nessimian in acknowledgment to his valuable contribution to the study of the Homoptera Cicadellidae in Brazil.

ACKNOWLEDGEMENTS. I am grateful to Prof. Luiz Antônio Pedreira Gonzaga (IB-UFRJ) and Dr. Johan Becker (MNRJ-UFRJ) for the revision of this paper, and to Prof. Elidiomar Ribeiro da Silva (IB-UFRJ) who helped a great deal with technical advince.

\section{BIBLOGRAPHIC REFERENCES}

DELONG, D.M. \& P.H. FREYTAG. 1969. Studies of the World Gyponinae (Homoptera: Cicadellidae). A Synopsis of the genus Clinonaria. Ohio J. Sci. 69 (3): 129-182. 

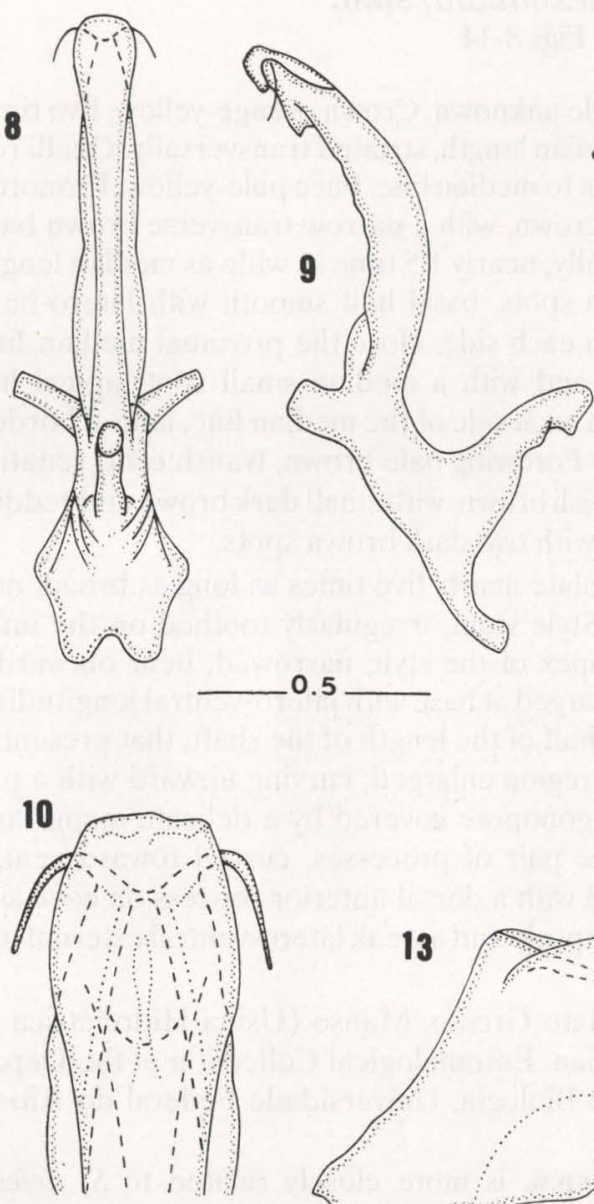

0.1
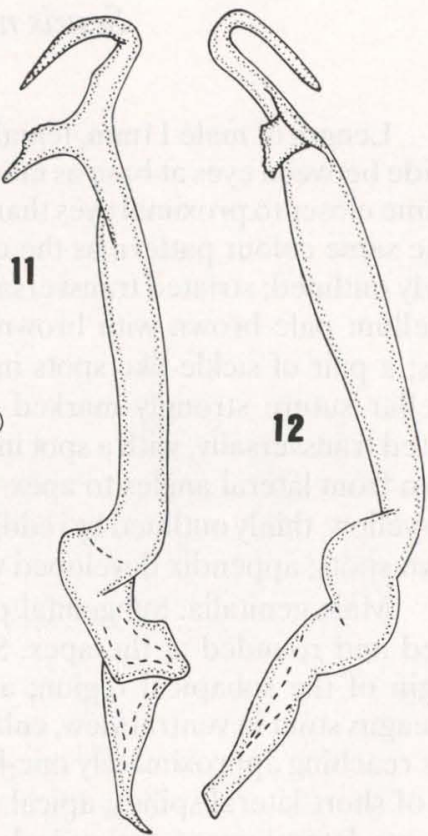

0.5

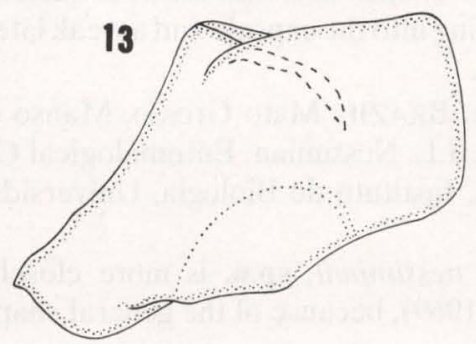

1.0

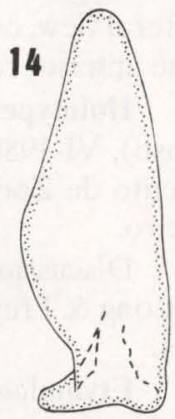

$-0.5$

Figs 8-14. Scaris nessimiani, sp.n. (8) Aedeagus, ventrally; (9) aedeagus, laterally; (10) apical region of the aedeagus, ventrally; (11) style, ventrally; (12) style, laterally; (13) pygofer, laterally; (14) subgenital plate, ventrally. Scale in milimeters.

Recebido em 29.X.1991; aceito em 25.XI.1993.

Revta bras. Zool. 10 (3): 399-402, 1993 